\title{
Postpartum period: the importance of home visits given by the nurse in Primary Health Care
}

\author{
Período puerperal: a importância da visita domiciliar para enfermeiros da Atenção Primária \\ à Saúde
}

Leticia dos Santos Medeiros ${ }^{1}$, Ana Carla Marques da Costa $^{1}$

\begin{abstract}
Objective: to understand the importance given by nurses working in primary health care for the realization of home visits in the puerperal period. Methods: qualitative research held with 38 nurses by applying a semistructured interview, in which the thematic content analysis technique was used under Bardin's theoretical light. Results: the majority of interviewees considered the home visit a tool that brings the health unit to the reality experienced by the mother, however, there are still many professionals who omit some precautions when dealing with this population. Conclusion: the home visit is considered essential for contributing to the reduction of morbidity and mortality of the postpartum and newborn, increasing the bond between unit and family, and reducing the risk of postpartum complications, however, the attention turned to these women is still covered with big challenges to achieve a real satisfactory assistance.
\end{abstract}

Descriptors: Primary Health Care; Postpartum Period; Home Visit; Nursing Care.

Objetivo: compreender a importância dada pelos enfermeiros atuantes na Atenção Primária à Saúde para realização da visita domiciliar no período puerperal. Métodos: pesquisa qualitativa, realizada com 38enfermeiros através da aplicação de uma entrevista semiestruturada, na qual utilizou-se a técnica da análise de conteúdo temática a luz teórica de Bardin. Resultados: a maioria dos entrevistados consideram a visita domiciliar, uma ferramenta que aproxima a unidade de saúde da realidade vivenciada pela puérpera, porém, ainda são muitos os profissionais que omitem certos cuidados frente a esta população. Conclusão: a visita domiciliar é considerada imprescindível, por contribuir para a redução da morbimortalidade da puérpera e recém-nascido, aumentar o vínculo entre unidade e família, e diminuir riscos de complicações pós-parto, no entanto, a atenção voltada a estas mulheres ainda está recoberta de grandes desafios para alcançar uma assistência de fato satisfatória.

Descritores: Atenção Primária à Saúde; Período Pós-Parto; Visita Domiciliar; Cuidados de Enfermagem.

${ }^{1}$ Faculdade de Ciências e Tecnologia do Maranhão. Caxias, MA, Brazil.

Corresponding author: Leticia dos Santos Medeiros

Rua Esperantenópolis, 1206. Vila Lobão - CEP: 65605-520 - Caxias, MA, Brazil. E-mail: leahmara.med@gmail.com 


\section{Introduction}

In the scenario of the Family Health Strategy, nurses render assistance to the women in general, with activities related to prenatal care, cervical and breast cancer, even to family planning, and to the postpartum period. Therefore, their duties are carried out in the environment of health facilities and at home, the latter, through home visits. This, in turn, is configured as a means of enabling the continuation of care provided to women during pregnancy and childbirth $^{(1)}$.

The home visit is understood as a strategic tool of care, which, according to the Health Department, is considered characteristic of the work process of primary care teams. Home care is aimed at patients who have their health problems either controlled or solved and difficulty or physical impairment of go to a health care unit, who need less frequent care and less need for health care resources ${ }^{(2)}$.

When it comes to women's health, the groups that are priorities for home care are highlighted, which are part of the home care to mothers, given that care during the postpartum period should be immediate, since it aims at individual and holistic assistance, establishing a bond of trust with the puerperal woman and her entire family ${ }^{(3)}$. At this time, primary care plays a key role especially in the educational process, it contributes directly to health promotion and the prevention of common diseases in this phase ${ }^{(4)}$.

Because the postpartum period is a phase that generates insecurity, whether or not it is the first experience for the mother, it is important that health professionals should be sensitive enough to identify the real needs of these women mainly at home ${ }^{(5)}$.

Therefore, this study aimed at understanding the importance given by nurses working in primary health care to provide home visits in the puerperal period.

\section{Methods}

This is a qualitative study, carried out in the Health Family Strategies distributed in Basic Health Units in urban and rural areas in the county of Caxias, MA, Brazil.

The participants of the study were nurses working in Basic Health Units in Caxias, Maranhao, registered in a Family Health Strategy of a urban or rural area of this county, and they are directly linked to the assistance turned to postpartum women during home visits, according to data from the Coordination of Basic Care of the county, totaling 53 nurses. Of those, 38 agreed to participate free and spontaneously in this study, 6 were not contacted because they were on vacation or on sick leave, and 9 did not agree to participate. The criteria of exclusion for the study were nurses who refused to participate in the study and/or were not registered in any of the Family Health Strategies in the county of Caxias, Maranhão.

Data collection happened in September and October, 2014. The data was collected through semistructured interview, in which the script of the interview consisted of two stages: the first contained the professional profile of the nurses interviewed, aimed at characterizing them and the second stage consisted of four open questions, in order to obtain the opinion of the importance of holding the postpartum home visit from these professionals. This study was guided by the following question: How important is the realization of postpartum home visit?

The approach of these professionals happened in a Basic Health Unit to which they belong, during working hours, when they were officially invited to participate in the study, and in cases of agreement, the mentioned interview was made and their statements were recorded in a MP4 player to ensure the confidentiality and anonymity of the study subjects, their names were replaced by the abbreviation (Nur.), 
added by a number that corresponds to the order in which the interviews were held.

After conducting and transcribing the interviews, the answers were submitted to the analysis of content of the Thematic Analysis Type, which is based on three distinct stages: the first concerns the pre-analysis, the second exploration of the material and processing of the results, and finally, the inference and interpretation of the obtained data are made ${ }^{(6)}$. After that, the results were classified into four categories: Home visits as a strategy to provide easy care; possibility of comprehensive care to mothers without home visits; continuing education for the professionals who provide home visits; the importance of home visits to the quality of life to the mother and child.

The study complied with the formal requirements contained in the national and international standards of regulatory research involving human subjects.

\section{Results}

Among the interviewees, 29 (76.3\%) are active in urban areas, while nine (23.7\%) in the rural areas. As to the education of the interviewees, most of them, had only graduation degree 23 (60.5\%), specialization 13 (34.2\%), master's two (5.3\%) nurses and none had a PhD degree. Concerning the time of graduation, none of the professionals $(0 \%)$ were graduated under one year, $11(28.9 \%)$ nurses were between one and three years of graduation, other 11 (28.9\%), between four and seven years, and between eight and 11 years of graduation, there were $(23.7 \%)$ nurses. Finally, professionals who had graduated for more than 11 years represent a total of seven (18.5\%) nurses.

The results presented below were distributed in accordance to the practices carried out, the knowledge, the perceptions and the participation of nurses facing their vision of the importance of the practice of postpartum home visit. At the end of the organization of the data, the categories of analysis that follow were obtained.

\section{Home visits as a strategy to easy care}

This first category reflects the opinions of nurses on home visits as a facilitating tool and not concerning the care to the mothers. In the statements presented, it is observed that nurses justify their statements according to the reality they experience in their fields. This can be confirmed in the statements that follow. For sure, especially because during this period, they are adapting to a new mother condition (Nur. 15). In fact, home visits make puerperal appointment easier, since most of the time the puerperal only attends the unit after 40 days of confinement, escaping the period considered postpartum (Nur. 17). Yes, because during the home visit we can assess the puerperal woman and the newborn, as well as guide her according to her needs (Nur. 38).

\section{Possibility of comprehensive care to mothers without home visits}

This category was organized into two subcategories: comprehensive care to mothers without the practice of home visits and home visits as an essential tool in comprehensive care for mothers.

The first category reveals the resistance of some professionals to conduct home visits to these women, claiming to be possible to guarantee all the care and assistance within the health unit. They even come with the baby to the unit to have the first appointment, so they can be assisted here (Nur. 2). It is possible to provide this assistance during the postpartum period, many times we guided the woman to come to the clinic (Nur. 11). We can do it, when the woman is aware, when the health agent also collaborates, often, the health professional ends up being our mediator when we cannot reach the woman (Nur. 15).

However, the second subcategory shows that nurses, mostly recognize that home visits to women during the postpartum period, is an indispensable tool and should be provided. We already have difficulty providing home care, I think it would have more difficulty even if I waited for the postpartum woman to come to the unit to have the 
puerperal appointment (Nur. 3). Without it (home visit), guidance, care and assessments can be jeopardized (Nur. 5). The visit has to be made, because they (mothers) say one thing, and you go to their houses and see the issue of social-economic conditions, everything is important and we evaluate all that, not only the woman and the child (Nur. 10). The home visit is necessary in the postnatal period so that the care is carried out in an integrated manner (Nur. 18).

\section{Continuing education for the professionals who provide home visits}

This third category was developed in order to show whether or not health professionals who carry out home visits to mothers are covered with health continuing education. No, it is difficult for us to have (continuing education) I will not lie (Nur. 3). We guide health professionals, because they are our link, and so we're always guiding them in what has to be done, as it should be (Nur. 10). No, this is a big problem or failure because most professionals are not trained and do not know how to treat or monitor the postpartum (Nur. 21). The continuing education is provided by Bemfam to health professionals as well as the training courses of the Open University of Unified Health System (Nur. 18). There is (continuing education), it's been a while there is not, but it happens (Nur. 26).

\section{The importance of home visits to the quality of life to the mother and child}

Finally, this last category openly reveals the importance that nurses provide home visits to mother and child. Some statements below show us such importance. It contributes to reduce maternal mortality, because in many cases, the woman dies due to bleeding, some other postpartum thing and also helps in reducing child mortality (Nur. 1). It is in the home visit that we can understand the daily life of that mother, including the difficulties. And then the mother who is visited, receives guidelines, and usually she can follow, because she feels valued by the professional who comes to her to provide information (Nur. 15). There is an increased link between the professional and the postpartum (Nur. 24). The importance on a scale of 5-10, is 10, since I and the doctor had a little misunderstanding, because I wanted to include puerperal visits in our weekly visits and he said no, that there was no need for it, bullshit, so I told him, well I will go, even if I go alone, but let me do it (Nur. 30).

\section{Discussion}

Regarding the issue home visits, this study reveals that the idea that the home visit makes assistance to women in the postpartum period easier is unanimous among the interviewed nurses. It is considered a tool that brings the health unit closer to the reality in which the postpartum, newborn and their family live, in addition, a home visit is configured in an important strategy in order to achieve completeness, incorporating practices of integration with other services. Thus, it represents an important issue in the reorganization of work in health and health care $^{(7)}$.

This information is reinforced in a survey, which noted the recurring idea that the home visit is an important facilitating means of services and health actions. This importance comes from the recognition of the visit as an instrument that facilitates access to the local health service in the household, the individualized care and a valued assistance technology, as well as expansion of equity to allow the approach of service to the needs of the population assisted ${ }^{(8)}$. Pointing out that the home visit is a strategy that enables a more intimate and individualized care, to know the reality and at the same time transfer confidence to women, answering their questions and so increase their performance as a mother ${ }^{(5)}$.

Corroborating the above data, it can be noted in this study that nurses, to recognize the home visit as a facilitator strategy of care, point to visit as a closer link with these women, and contribute to adapt to their new condition as a mother, providing a comprehensive and individualized care, according to the needs of each postpartum.

However, despite revealing the easiness of care through home visits and showing being conscious of the benefits that the visit provides, there are still many health professionals who directly or indirectly omit those actions facing the priority population, 
especially the puerperal women. Furthermore, a considerable number of nurses claim to be feasible to meet the needs of postpartum women without the practice of home visits, when it can be directed to the unit or even when care happens through the community health worker. Therefore, it is evident that there is lack of scientific knowledge of some nurses, about the size of the benefits that home visit provides to the puerperal women, besides the omission of this tool, which is a right of the patient, including the puerperal women. This paragraph concerns only the research in question.

These data lead us to discredit the efficiency of the actions proposed by some nurses, which contradicts a study that says that the use of home visits as a key instrument for the practice of nursing in the context of the Family Health Strategy, should be further promoted by nurses, because in the long run, it has a beneficial effect on the health of the woman and the baby, besides strengthening the family link with the health care $^{(9)}$.

Corroborating these findings, it is emphasized that, creating a relationship to the support care infer in the feelings experienced by the women, providing security to develop their new roles as home visits are able to strengthen the interaction between nursing and the postpartum women, it is also believed that the nurse is the mediator of this link between the postpartum woman and the other health professionals. The home care provides more comfort and opportunity for the mothers of newborns to present their actual living conditions, allowing nurses to relate this fact to the needs identified, as well as necessary nurse care ,possible to be carried out, making it real and humanized ${ }^{(5)}$.

It is important to highlight that the postpartum period is characterized by a time of new and significant events in the life of the woman who longs for professional support which offers satisfactory assistance able to meet their needs and expectations, minimizing their doubts as well as developing care related to self-confidence and empowerment which are indispensable to have a healthy maternal performance ${ }^{(1)}$. This highlights factors that justify the need for a quality support in the Family Health Strategy through home visits. So, there are no possibilities to assist all the needs of the puerperal woman, without the practice of home visits by professionals of Primary Health Care, as evidenced in this research the absence of that activity in some cases.

Due to its organization, primary care was constituted as the first contact of the patients with the health system. Guided by the principles of universality, accessibility (to the system), continuity, integrity, accountability, humanization, bond, equity and social participation. Home care is an activity inherent in the work process of primary care teams, requiring trained professionals to identify and care for the patients who will benefit from this type of attention, which means ensuring certain aspects of the organization of the process of work as well as adding certain technologies required to achieve the health care at home ${ }^{(10)}$.

Thus, continuing education should be used as a continuous process of training of health professionals, and the Basic Health Unit is where education should be. Stressing that it is the responsibility of the nurse, to plan and coordinate the training and continuing education for the nursing team and community health workers, providing them with the participation of other members of the health team ${ }^{(11)}$. Corroborating this statement, you can see according to the survey, that some nurses are concerned to share relevant information mainly with community health agents, because they are the ones who link the health unit and the postpartum women, thus facilitating the accession of knowledge about appropriate care during this phase.

However, this research showed that most nurses said that there was no continued education in their unit. This fact leads us to say that some professionals do not bother to seek training or empower their team, as the practice of home visits is not only the nurse's job but of the entire multidisciplinary team. It is necessary to point out that among the interviewed 
nurses; a minority says that although there is no active practice of continuing education, they seek to improve their practices through courses out of the unit.

The knowledge of care in the postpartum period is essential for professionals in the primary health care, since they are the main mediators of care for mothers, however, there are still many professionals who do not update themselves about the subject. Going along with these data, a study observed a discrete production of knowledge on postpartum home visit. It was also identified that the knowledge produced about nursing care during the postpartum period at home is scarce, given the impact felt by nurses in providing home visits and, on the other hand, the needs presented by the mothers, beyond the physiological needs. It is up to the nurse, to provide a closer cooperation between the postpartum and the multidisciplinary team of health, which is the basis for the quality of the care provided ${ }^{(5)}$.

Another research found that most health professionals had a good relationship with the team and domain with their work. However, there was a low frequency of team meetings, and little discussion focused on work processes and planning of actions as well as the lack of continuing education activities ${ }^{(12)}$.

In contrast, a home visit is shown as an extremely important resource in the context of health care to the family, but teams must planned it and insert it in a project of assistance actions of interdisciplinary character turned to the health of the family. For such, the teams need to be trained for the visit, with a theoretical, methodological and technical preparation in order to ensure satisfactory care $^{(13)}$. Thus, the importance of continuing education to professionals in the primary health care is evident, especially nurses, as this is primarily responsible to train other professionals in their unit.

Regarding the importance of postpartum home visit, the Health Department points out that home visits to postpartum and newborn should happen in the first week after delivery, since morbidity situations and maternal and neonatal mortality, in good part, soon happen in this period ${ }^{(14)}$. This is the main factor that justifies the nursing care to this group, since it is through this care that both mother and newborn greatly reduce the chances of health problems.

Corroborating these data, the survey reveals that a minority of the interviewees highlight the importance of home visits as a predominant factor in the reduction of cases of morbidity and mortality. In this regard, point out that the home visit is considered one of the most effective tools within the health care system, in order to provide quality care to family health in general, with the aim, above all, at reducing morbidity and maternal and neonatal mortality ${ }^{(15)}$.

Some participants also emphasize the influence of home visits in increasing the link between the health unit and the postpartum. Most professionals recognize the visit as a way to discover the needs of each postpartum and newborn, thus contributing to a care that meets best the needs of each one. According to these data, home visits give the nurse a unique moment in which the domicile of postpartum women is considered an extremely important environment, where they perform their activities without interruption or concerns with other professional skills. In addition, the listening occurred during their home visits strengthen the bond nurse/ postpartum women and promotes an open and adequate scenario for any questions and concerns experienced during the period by the mother ${ }^{(9)}$.

The postpartum period is a time of extreme importance in the life of a woman, it is a rite of passage that must be experienced in a positive way, and nursing is in a privileged position when it comes to care for women who experience this time as incorporating the art of care in a humane manner, respecting the rights of women to a safe and pleasurable maternity ${ }^{(16)}$.

Home visits are very important activities for the detection and/or prevention of problems that affect the proper course of pregnancy and postpartum, not always conceivable in consultations of prenatal and postpartum ${ }^{(17)}$. It is clear that, home visits to the woman and the newborn, are indispensable, 
because according to the survey and some studies, they provide benefits that professionals might not reach within their units. Thus, they emphasize the necessity of addressing these mothers in their home environment, to meet, whenever possible, the needs of the postpartum and newborn, as well as the whole family.

\section{Final Considerations}

The study revealed that nurses consider home visits a facilitating strategic tool of the Unified Health System, to contribute in the care, revealing the professionals the real needs experienced by their patients. Despite this statement, some professionals do not make home visits, and wait for the postpartum women to go to the unit for their postpartum appointment, or give this activity to the community health agent, even aware of their role within the primary health care. This fact can be explained by the shortage of professionals in the health network, claiming to perform or participate in continuing education activities, as evidenced in the survey.

Despite the evident shortcomings in some home visits, they were assessed by nurses as a fundamentally important tool for assisting the postpartum and newborn. Home visits contribute to the reduction of cases of morbidity and maternal and neonatal mortality, increase the bond with the mothers of newborns and contribute to a comprehensive, holistic and continuous care. Therefore, it is important to note that the attention focused on the health of women during the postpartum period, is still covered with great challenges to satisfactorily reach assistance. In this sense, the importance of alerting nurses to the effective practice of postpartum home visit is evidenced, because so far, it is the best way to prevent disease and injuries at this stage.

It is important to highlight that the study has limitations, as a survey held in one county and covered only the professional nurses working in Primary Health Care. Therefore, it is necessary to have an investigation with all primary care professionals in order to have overall results. For such, the results can guide further research on the importance of holding the postpartum home visit within the Primary Health Care.

\section{Acknowledgement}

The Fundação de Amparo à Pesquisa e ao Desenvolvimento Científico e Tecnológico of Maranhão, Brazil, which financed the research under Process No. 00168/16.

\section{Collaborations}

Medeiros LS contributed to the work of the design, data collection, analysis, data interpretation, writing of the article and final approval of the version to be published. Costa ACM contributed to the design of the project, relevant critical revision and final approval of the version to be published.

\section{References}

1. Mazzo MHSN, Brito RS, Santos FAPS. Atividades do enfermeiro durante a visita domiciliar pós-parto. Rev Enferm UERJ. 2014; 22(5):663-7.

2. Ministério da Saúde (BR). Política Nacional de Atenção Básica. Brasília: Ministério da Saúde; 2012.

3. Oliveira VS, Ximenes VL. Consulta de Enfermagem no pós-natal. In: Santos LGA, Andreto LM, Figueira MCS, Morimura MCR, Germano EM, Melo EMVB. Enfermagem em ginecologia e obstetrícia. Rio de Janeiro: MedBook; 2010. p. 239-51.

4. Guerreiro EM, Rodrigues DP, Queiroz ABA, Ferreira MA. Educação em saúde no ciclo gravídicopuerperal: sentidos atribuídos por puérperas. Rev Bras Enferm. 2014; 67(1):13-21.

5. Bernardi MC, Carraro TE, Sebold LF. Visita domiciliária puerperal como estratégia de cuidado de enfermagem na atenção básica: revisão integrativa. Rev Rene. 2011; 12 (n.esp.):1074-80. 
6. Bardin L. Análise de conteúdo. São Paulo: Edições 70; 2011.

7. Brito MJM, Andrade AM, Caçador BS, Freitas LFC, Penna CMM. Atenção domiciliar na estruturação da rede de atenção a saúde: trilhando os caminhos da integralidade. Esc Anna Nery. 2013; 17(4):60310.

8. Cruz MM, Bourget MMM. A visita domiciliária na estratégia de saúde da família: conhecendo as percepções das famílias. Saúde Soc. 2010; 19(3):605-13.

9. Pereira MC, Gradim CVC. Consulta puerperal: a visão do enfermeiro e da puérpera. Ciênc Cuid Saúde. 2014; 13(1):35-42.

10. Ministério da Saúde (BR). Secretaria de Atenção à Saúde. Caderno de atenção domiciliar. Brasília: Ministério da Saúde; 2012.

11. Souza ASR, Rodrigues AMS, Augusto DK, Guimarães FG, Xavier JAS, Ramos LS, et al. Protocolos de atenção à saúde da mulher: pré-natal e puerpério. [Internet]. 2009 [citado 2014 set 13]. Disponível em:http://www.pbh.gov.br/smsa/biblioteca/ atmulher/prot_pre_natal_prot_pre_natal.qxd.pdf

12. Cunha MS, Sá MC. A visita domiciliar na estratégia de saúde da família: os desafios de se mover no território. Interface Comun Saúde. 2013; 17(44):61-73.
13. Gaiva MAM, Siqueira VCA. A prática da visita domiciliária pelos profissionais da estratégia saúde da família. Ciênc Cuid Saúde. 2011; 10(4):697-704.

14. Ministério da Saúde (BR). Atenção ao pré-natal de baixo risco. Brasília: Ministério da Saúde; 2012.

15. Ximenes Neto FRG, Chaves ME, Ponte MAC, Cunha ICKO. Trabalho do enfermeiro da estratégia saúde da família na visita ao lar da puérpera e recémnascido. Rev Soc Bras Enferm Pediatr. 2012; 12(1):27-36.

16. Pereira MC, Garcia ESGF, Andrade MBT, Gradim CVC. Sentimentos da puérpera primípara nos cuidados com o recém-nascido. Cogitare Enferm. 2012; 17(3):537-42.

17. Garcia ESGF, Leite EPRC, Nogueira DA. Nursing care to puerperal women in primary care units. Rev Enferm UFPE on line [Internet]. 2013 [cited 2015 Jan 09]; 7(10):5923-8. Available from: http://www.revista.ufpe.br/revistaenfermagem/ index.php/revista/article/download/4836/7397 